\title{
Crude extract of the tropical tree Gallesia integrifolia (Phytolaccaceae) for the control of Aedes aegypti (Diptera: Culicidae) larvae
}

\author{
Wanessa de Campos Bortolucci ${ }^{1}$, Herika Line Marko de Oliveira ${ }^{1}$, Leiluana Roque Oliva ${ }^{2}$, \\ José Eduardo Gonçalves ${ }^{2,3}$, Ranulfo Piau Júnior ${ }^{4}$, Carla Maria Mariano Fernandez ${ }^{1}$, \\ Nelson Barros Colauto ${ }^{1}$, Giani Andrea Linde ${ }^{1} \&$ Zilda Cristiani Gazim ${ }^{1 *}$ \\ 1. Universidade Paranaense, Umuarama-PR, Brazil; wanessa.bortolucci@edu.unipar.br, herika.marko@edu.unipar.br, \\ carlamfernandez@prof.unipar.br,nbc@prof.unipar.br, gianilinde@prof.unipar.br, cristianigazim@prof.unipar.br \\ 2. UniCesumar, Maringá-PR, Brazil; leiluana.oliva@gmail.com, jose.goncalves@unicesumar.edu.br \\ 3. Cesumar Institute of Science, Technology and Innovation - ICETI, UniCesumar, Maringá-PR, Brazil. \\ 4. Graduate Program in Animal Science with emphasis on Bioactive Products. Universidade Paranaense, Umuarama-PR, \\ Brazil; piau@prof.unipar.br \\ * Correspondence
}

Received 26-III-2020. Corrected 12-X-2020. Accepted 11-XI-2020.

\begin{abstract}
Introduction: Phytoinsecticides are alternatives to control insects in different stages, Gallesia integrifolia (Spreng.) Harms, Phytolacaceae family, popularly known as pau d'alho, garlic tree, and guararema in Brazil, is known due to its strong alliaceous odor because of the presence of sulfur molecules in the plant. This species presents biological activity and potential insecticide effect that is still unexploited. Objective: This study aimed to evaluate the biological activity of the ethanolic crude extract from G. integrifolia leaves, flowers, and fruits on the control of Aedes aegypti third-stage larvae and pupae. Methods: The botanical material was

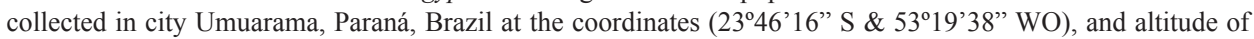
$442 \mathrm{~m}$, the fruits of $G$. integrifolia were collected in May and the leaves and flowers in December 2017. The crude extracts of $G$. integrifolia leaves, flowers, and fruits were prepared by dynamic maceration technique. The chemical composition of the extracts was determined by gas chromatography coupled to a mass spectrometry. The insecticidal activity of the crude extracts of $G$. integrifolia were carried out on larvae and pupae of $A$. aegypti in concentrations between 0.001 to $25000 \mathrm{mg} / \mathrm{mL}$, and afterwards the lethal concentrations that kill 50 $\%\left(\mathrm{LC}_{50}\right)$ and $99.9 \%\left(\mathrm{LC}_{99.9}\right)$ were determined by probit analysis. Anticholinesterase activity was determined by bioautographic method at concentrations from 0.000095 to $50 \mathrm{mg} / \mathrm{mL}$. Results: The yield of G. integrifolia crude extracts were 8.2, 9.1, and $17.3 \%$ for flowers, fruits, and leaves, respectively. The chemical composition of $G$. integrifolia extracts was characterized by presence of fatty acid esters, phytosterols, vitamins, oxygenated diterpenes and organosulfur compounds. The flower extract presented the high amount of sulfur compounds $(20.2 \%)$ such as disulfide, bis (2-sulfhydryl ethyl) (11.9\%), 2,3,5-trithiahexane (6.2\%), 1,2,4-trithiolane (1.1 $\%)$, and 2,4-dithiapentane (1.1\%). Regarding the insecticidal activity, flower extract showed highly active with $\mathrm{LC}_{99.9}$ of $0.032 \mathrm{mg} / \mathrm{mL}$ and $\mathrm{LC}_{99.9}$ of $0.969 \mathrm{mg} / \mathrm{mL}$ on $A$. aegypti larvae and pupae, respectively, and the highest inhibition of acetylcholinesterase enzyme $(0.00019 \mathrm{mg} / \mathrm{mL})$ ex situ. The flower extract presented anticholinesterase and larvicide activity, respectively, $12.8 \%$ and $35.6 \%$ greater than the control temephos. Conclusions: This study opens new perspectives on the use of extracts from $G$. integrifolia as a bioinsecticide alternative for the control of $A$. aegypti larvae and pupae.
\end{abstract}

Key words: anticholinesterase; disulfide; bis(2-sulfhydryl ethyl); pau d'alho; semiochemical; sulfur compounds.

de Campos Bortolucci, W., Marko de Oliveira, H.L., Roque Oliva, L., Gonçalves, J.E., Piau Júnior, R., Mariano Fernandez, C.M., Barros Colauto, N., Linde, G.A., \& Gazim, Z.C. (2021). Crude extract of the tropical tree Gallesia integrifolia (Phytolaccaceae) for the control of Aedes aegypti (Diptera: Culicidae) larvae. Revista de Biología Tropical, 69(1), 153-169. DOI 10.15517/rbt.v69i1.41225 
Aedes aegypti (Linnaues, 1762) is the main vector of arboviruses such as dengue, chikungunya fever, Zika virus and yellow fever (Fofana, Beugré, Yao-Acapovi, \& Lendzele, 2019). The combat to disseminate this mosquito is a challenge in tropical countries, mainly in South America, and a problem to health due to the high morbidity and mortality rates (Pavela, 2015; Benelli \& Mehlhorn, 2016; González et al., 2019). In Brazil, in 2019, there were 1544 987 recorded cases of dengue with 782 deaths, besides 132205 cases of chikungunya with 92 deaths, and 10768 cases of Zika virus with three deaths (Ministério da Saúde, 2020).

Synthetic chemical insecticides from organophosphate class are utilized against $A$. aegypti, mainly temephos, an organothiophosphate insecticide (Benelli et al., 2017). However, organothiophosphates are reported to have genotoxic action on human hepatic cells (Benitez-Trinidad et al., 2015) and neural damages in rats (Laurentino et al., 2019). Besides, the broad action spectrum of this insecticide causes non-specific deaths of insects (Braga \& Valle, 2007; Čolović \& Krstić, 2013; Mrdaković et al., 2016), bees, butterflies, and other pollinating insects (Morais, Bautista, \& Viana, 2000). Moreover, the increased concentration of this insecticide in Brazilian cities indicates that there is a resistance process to this chemical to control A. aegypti (Jonny, Silva, Fantinatti, $\&$ Silva, 2015). An alternative to organophosphates for the control of $A$. aegypti are the noncumulative synthetic pyrethroids which are, however, toxic to aquatic arthropods, fish, and bees, eliminating essential insects that act on the biological control of insects, besides causing adverse effect to human health due to long exposure to it (Camargo et al., 1998; Bellinato et al., 2016).

Another alternative to organophosphates would be phytoinsecticides such as essential oils that in general have a quicker degradation and/or volatilization, causing smaller environmental damage, mainly to pollinating insects. For instance, to control Varroa destructor that parasites bees, essential oils of neem (Azadirachta indica), lemon (Citrus limon), and eucalyptus (Eucalyptus citriodora, current name Corymbia citriodora) are utilized without killing the beehive (Bakar et al., 2017). However, some phytoinsecticides can have a similar action to organophosphates such as the garlic essential oil (Allium tuberosum and Allium sativum) used to control larvae and/or repel mosquitoes such as Aedes spp., Anopheles spp., and Culex spp. (Denloye, Makanjuola, \& Babalola, 2003; Trongtokit, Rongsriyam, Komalamisra, \& Apiwathnasorn, 2005; Raimundo et al., 2018).

Gallesia integrifolia (Spreng.) Harms, Phytolacaceae family, popular names pau d'alho, garlic tree, and guararema in Brazil, is known due to its strong alliaceous odor because of the presence of sulfur molecules in the plant, despite not belonging to the Alliaceae family (Barbosa, Teixeira, \& Demuner, 1997; Sambuichi, Mielke, \& Pereira, 2009). It has several synonyms such as Gallesia gorazema, Gallesia integrifolia var. ovata, Gallesia ovata, Gallesia scorododendrum, and Thouinia integrifolia (Hassler, 2018). This plant has been reported since 1821 for common treatments of orchitis, verminosis, and rheumatism (CorrêaFilho, 1984; Akisue, Akisue, \& Oliveira, 1986), and the essential oil has been reported to act against bovine tick (Rhipicephalus microplus) (Raimundo et al., 2017) and to have antifungal activity (Raimundo et al., 2018).

The aqueous crude extract of $G$. integrifolia leaves are used in organic agriculture to control Botrytis cinerea during pre- and postharvest of grapes in viniculture (Silva et al., 2017). Hydroalcoholic extracts of G. integrifolia leaves were effective to control eggs and larvae of bovine ticks (Rhipicephalus microplus) (Dias, Tanure, \& Bertonceli, 2018). The hydroethanolic extract of $G$. integrifolia inner bark had bacteriostatic activity and no toxicity to epithelial cells of Chinese hamster ovary (Arunachalam et al., 2016). The dichloromethane and methanolic extracts of $G$. integrifolia bark had antifungal activity (Freixa et al., 1998). Moreover, dichloromethane extract of $G$. integrifolia roots has antinociceptive and antiinflammatory activities in vivo with mice and 
antiviral activity against herpes simplex virus (Silva et al., 2013). In addition, riverside dwellers usually burn $G$. integrifolia dried leaves to repel mosquitoes from the genus Anopheles, vector of malaria, showing its potential biocide activity (Pérez, 2002). However, despite these reports, there are no studies on the extract from G. integrifolia leaves to control insect, mainly A. aegypti. Thus, this study aimed to evaluate the biological activity of the ethanolic crude extracts from $G$. integrifolia leaves, flowers, and fruits to control A. aegypti third-stage larvae and pupae to develop an alternative for the control of this insect.

\section{MATERIALS AND METHODS}

Plant material: fruits, leaves, and flowers of $G$. integrifolia were harvested in Umuarama at the coordinates $\left(23^{\circ} 46^{\prime} 16^{\prime \prime} \mathrm{S} \& 53^{\circ} 19^{\prime} 38^{\prime \prime}\right.$ WO) and altitude of $442 \mathrm{~m}$. Leaves and flowers were harvested in the morning in December 2017 and fruits were harvested in the morning in May 2017. The plant was identified and a sample was deposited in the Herbarium of Western Paraná State University, Cascavel Campus, Center of Biological Sciences and Health, under the number 1716 . This species was registered in the National System for the Management of Genetic Heritage and Associated Traditional Knowledge (SisGen, acronym in Portuguese) under the registration number A0A10E1.

Crude extract preparation: leaves, flowers, and fruits of $G$. integrifolia $(500 \mathrm{~g})$ were pulverized to $850 \mu \mathrm{m}$ with a knife mill (Willye TE-650) and three extracts were obtained after dynamic maceration with solvent (ethanol 96 ${ }^{\circ} \mathrm{GL}$ ) depletion. The extracts were filtered and the solvent was removed in a rotating evaporator (Tecnal TE-210) at $40{ }^{\circ} \mathrm{C}$. The yield of each crude extract (dry basis) was calculated in triplicate by the mass of the obtained crude extract (g) divided by the mass of the vegetal matter (leaves, flowers, or fruits) (g), multiplied by 100 and expressed in percentage (Ministério da Saúde, 2010).

\section{Chemical characterization of the crude} extract: for the chemical identification of the compounds, the crude extracts from $G$. integrifolia leaves, flowers, and fruits $(100 \mathrm{mg})$ were analyzed by gas chromatography (Agilent 19091S-433) coupled to a mass spectrophotometer (Agilent 19091J-433) (CG-MS). An HP-5MS UI $5 \%$ analytical column $(30 \mathrm{~m} \times$ $0.25 \mathrm{~mm} \times 0.25 \mu \mathrm{m}$ ) was utilized with an initial temperature of $60{ }^{\circ} \mathrm{C}$, and kept for $3 \mathrm{~min}$. Then, a ramp of $5{ }^{\circ} \mathrm{C} / \mathrm{min}$ and the temperature was increased to $300{ }^{\circ} \mathrm{C}$ and kept for $10 \mathrm{~min}$ and, finally, to $310^{\circ} \mathrm{C}$ with a ramp of $10{ }^{\circ} \mathrm{C} /$ min for $10 \mathrm{~min}$. Helium was utilized as the carrier gas at the linear speed of $1 \mathrm{~mL} / \mathrm{min}$ until $300{ }^{\circ} \mathrm{C}$ and pressure release of $56 \mathrm{kPa}$. The injector temperature was $300{ }^{\circ} \mathrm{C}$; the injection volume was $2 \mu \mathrm{L}$; the injection was in split mode (20:1). The transfer line was kept at 285 ${ }^{\circ} \mathrm{C}$ and the ionization source and quadrupole at $230{ }^{\circ} \mathrm{C}$ and $150{ }^{\circ} \mathrm{C}$, respectively. The MS detection system was utilized in scan mode, in the range of mass/load ratio $(\mathrm{m} / \mathrm{z})$ of $40-550$ with 3 min solvent delay. The compounds were identified by comparing their mass spectra with the ones from Wiley 275 libraries, and comparing their retention indices (RI) obtained by a homologous series of $n$-alkane standards $\left(\mathrm{C}_{7}{ }^{-}\right.$ $\mathrm{C}_{40}$ ) (Adams, 2017).

Insecticidal activity: Aedes aegypti thirdstage larvae and pupae were obtained from the Department of Sanitary Surveillance of Umuarama, Paraná, Brazil. The extracts were diluted from 0.001 to $25000 \mathrm{mg} / \mathrm{mL}$ in an aqueous solution containing $20 \mathrm{~mL} / \mathrm{L}$ polysorbate-80. Ten $A$. aegypti larvae were placed in $25 \mathrm{~mL}$ flasks with $1.0 \mathrm{~mL}$ extract solution at different concentrations and kept in the dark at room temperature for $24 \mathrm{~h}$ (Costa et al., 2005; Fernandes, Souza Freitas, da Costa, \& da Silva, 2005; Bonato, Cavalca, \& Lolis, 2010). Larvae without movement and response to stimuli were considered dead (Bonato et al., 2010). The same procedure was used for $A$. aegypti pupae. The negative control was $20 \mathrm{~mL} / \mathrm{L}$ polysorbate- 80 aqueous solution and the positive control was the organothiophosphate temephos 
at the concentration ranging from 0.009 to 500 $\mathrm{mg} / \mathrm{mL}$ (Macoris, Camargo, Silva, Takaku, \& Andrighetti, 1995; Camargo et al., 1998). Lethal concentrations $\left(\mathrm{LC}_{50}\right.$ and $\left.\mathrm{LC}_{99.9}\right)$ were calculated by the probit analysis.

Anticholinesterase activity: the anticholinesterase activity was determined by the bioautographic method according to Marston, Kissling, \& Hostettmann (2002) with modifications (Yang et al., 2009). The methanolic solutions of the leaf, flower, and fruit extracts, and the positive control temephos were tested at concentrations varying from 50 to 0.000095 $\mathrm{mg} / \mathrm{mL}$ (in methanol). The samples were plotted in aluminum TLC (thin-layer chromatography) plates $(10 \times 10 \mathrm{~cm} ; 0.2 \mathrm{~mm}$-thick 60 F254 silica gel), dried and sprayed with an acetylcholinesterase enzyme $(500 \mathrm{U} / \mathrm{mL})$ solution in a buffer solution of tris (hydroxymethyl) aminomethane hydrochloridrate $(0.05 \mathrm{M}, \mathrm{pH}$ 7.8 ), sprayed with an $\alpha$-naphthyl acetate solution $(0.15 \%)$ and kept at $37{ }^{\circ} \mathrm{C}$ for $20 \mathrm{~min}$. After that, the chromo plates were sprayed with fast blue B salt colorimetric reagent $(0.05 \%)$ resulting in a purple color surface. The anticholinesterase activity of each $G$. integrifolia crude extract was determined by the emergence of white stains after $10 \mathrm{~min}$, showing the inhibitory action of the evaluated concentration on the enzyme activity by contrasting with the purple color of the colorimetric reagent. Temephos was used at the same concentrations of the crude extracts as a positive control.

Statistical analysis: the experimental design was completely randomized and all assays carried out in triplicate. Data were submitted to analysis of variance (ANOVA) and compared utilizing SPSS statistics 22 program by Duncan test $(\mathrm{P} \leq 0.05)$. Lethal concentrations $\left(\mathrm{LC}_{50}\right.$ and $\left.\mathrm{LC}_{99.9}\right)$ and confidence intervals were calculated by probit analysis.

\section{RESULTS}

The yield of the crude extracts from $G$. integrifolia flowers, fruits, and leaves was 8.2, 9.1 , and $17.3 \%$, respectively, with the greatest yield for the leaf extract. The chemical identification of the extracts showed 20 chemical compounds in the flowers, 22 in the fruits, and 17 in the leaves, considering only the compounds in the relative area greater than $0.5 \%$ (Table 1 ). The major compounds of the ethanolic extract from $G$. integrifolia flowers were vitamin E $(18.0 \%)$ and disulfide, ethyl iso-allocholate (10.6\%), from fruits were vitamin E $(20.9 \%)$, linolenic acid methyl ester (14.0\%), disulfide, bis(2-sulfhydryl ethyl) (11.9\%), and phytol $(10.2 \%)$, whereas from leaves were phytol (30.9\%), linolenic acid methyl ester (30.5\%), and methyl palmitate $(10.9 \%)$.

TABLE 1

Chemical composition obtained by gas chromatography-mass spectrometry of the extracts from Gallesia integrifolia leaf, flower, and fruit

\begin{tabular}{|c|c|c|c|c|c|c|c|c|}
\hline \multirow{2}{*}{ Peak } & \multirow{2}{*}{${ }^{\mathrm{a} C}$ Compound } & \multirow{2}{*}{${ }^{\mathrm{a}} \mathrm{RI}_{\text {calc }}$} & \multicolumn{3}{|c|}{ Relative area (\%) } & \multirow{2}{*}{$\mathrm{m} / \mathrm{z}$} & \multirow{2}{*}{ Structure } & \multirow{2}{*}{${ }^{\mathrm{c}} \mathrm{MS}$} \\
\hline & & & Leaves & Flowers & Fruits & & & \\
\hline 1 & 2,4-dithiapentane & 808 & - & 1.06 & 2.12 & 108.01 & $\mathrm{C}_{3} \mathrm{H}_{8} \mathrm{~S}_{2}$ & $\mathrm{a}, \mathrm{b}, \mathrm{c}$ \\
\hline 2 & 1,2,4-trithiolane & 810 & 0.86 & 1.10 & 1.76 & 124.23 & $\mathrm{C}_{2} \mathrm{H}_{4} \mathrm{~S}_{3}$ & $a, b, c$ \\
\hline 3 & R-limonene & 847 & - & 0.91 & - & 139.98 & $\mathrm{C}_{10} \mathrm{H}_{16} \mathrm{O}_{3}$ & $\mathrm{a}, \mathrm{b}, \mathrm{c}$ \\
\hline 4 & 2,3,5-trithiahexane & 885 & - & 6.17 & 4.67 & 140.27 & $\mathrm{C}_{3} \mathrm{H}_{8} \mathrm{~S}_{3}$ & $\mathrm{a}, \mathrm{b}, \mathrm{c}$ \\
\hline 5 & Disulfide, bis(2-sulfhydryl ethyl) & 935 & - & 11.91 & - & 185.96 & $\mathrm{C}_{4} \mathrm{H}_{10} \mathrm{~S}_{4}$ & $\mathrm{a}, \mathrm{b}, \mathrm{c}$ \\
\hline 6 & Cedr-8-en-13-ol & 936 & - & 0.93 & - & 220.18 & $\mathrm{C}_{15} \mathrm{H}_{24} \mathrm{O}$ & $\mathrm{a}, \mathrm{b}, \mathrm{c}$ \\
\hline 7 & n-hexadecanoic acid & 937 & - & 5.57 & 1.04 & 256.24 & $\mathrm{C}_{16} \mathrm{H}_{32} \mathrm{O}_{2}$ & $\mathrm{a}, \mathrm{b}, \mathrm{c}$ \\
\hline 8 & Palmitoleic acid, methyl ester & 938 & 1.57 & - & - & 268.24 & $\mathrm{C}_{17} \mathrm{H}_{32} \mathrm{O}_{2}$ & $\mathrm{a}, \mathrm{b}, \mathrm{c}$ \\
\hline 9 & Methyl palmitate & 949 & 10.91 & 4.69 & 5.05 & 270.26 & $\mathrm{C}_{17} \mathrm{H}_{34} \mathrm{O}_{2}$ & $a, b, c$ \\
\hline
\end{tabular}


TABLE 1 (Continued)

\begin{tabular}{|c|c|c|c|c|c|c|c|c|}
\hline \multirow{2}{*}{ Peak } & \multirow{2}{*}{${ }^{\mathrm{a} C o m p o u n d}$} & \multirow{2}{*}{${ }^{\mathrm{a}} \mathrm{RI}_{\text {calc }}$} & \multicolumn{3}{|c|}{ Relative area $(\%)$} & \multirow{2}{*}{$\mathrm{m} / \mathrm{z}$} & \multirow{2}{*}{ Structure } & \multirow{2}{*}{${ }^{\mathrm{c}} \mathrm{MS}$} \\
\hline & & & Leaves & Flowers & Fruits & & & \\
\hline 10 & Linoleic acid & 973 & 5.99 & - & - & 280.45 & $\mathrm{C}_{18} \mathrm{H}_{32} \mathrm{O}_{2}$ & $\mathrm{a}, \mathrm{b}, \mathrm{c}$ \\
\hline 11 & Ethyl palmitate & 1099 & 1.43 & - & 2.11 & 284.48 & $\mathrm{C}_{18} \mathrm{H}_{36} \mathrm{O}_{2}$ & $a, b, c$ \\
\hline 12 & Stearic acid & 1100 & 1.05 & - & - & 284.28 & $\mathrm{C}_{18} \mathrm{H}_{36} \mathrm{O}_{2}$ & $\mathrm{a}, \mathrm{b}, \mathrm{c}$ \\
\hline 13 & Linolenic acid methyl ester & 1101 & 30.53 & - & 4.54 & 292.24 & $\mathrm{C}_{19} \mathrm{H}_{32} \mathrm{O}_{2}$ & $\mathrm{a}, \mathrm{b}, \mathrm{c}$ \\
\hline 14 & 10,13-octadecadienoic acid, Methyl ester & 1103 & - & 6.07 & 5.04 & 294.26 & $\mathrm{C}_{19} \mathrm{H}_{36} \mathrm{O}_{2}$ & $\mathrm{a}, \mathrm{b}, \mathrm{c}$ \\
\hline 15 & Methyl linoleate & 1107 & - & 5.17 & - & 294.47 & $\mathrm{C}_{19} \mathrm{H}_{34} \mathrm{O}_{2}$ & $\mathrm{a}, \mathrm{b}, \mathrm{c}$ \\
\hline 18 & Phytol & 1137 & 30.92 & 10.24 & 6.50 & 296.31 & $\mathrm{C}_{20} \mathrm{H}_{40} \mathrm{O}$ & $\mathrm{a}, \mathrm{b}, \mathrm{c}$ \\
\hline 19 & Linoleic acid ethyl ester & 1171 & 3.87 & 14.00 & 2.28 & 308.27 & $\mathrm{C}_{20} \mathrm{H}_{36} \mathrm{O}_{2}$ & $\mathrm{a}, \mathrm{b}, \mathrm{c}$ \\
\hline 20 & Ethyl octadecanoate & 1174 & - & 0.55 & - & 312.30 & $\mathrm{C}_{20} \mathrm{H}_{40} \mathrm{O}_{2}$ & $\mathrm{a}, \mathrm{b}, \mathrm{c}$ \\
\hline 22 & $\alpha$-monoolein & 1262 & - & - & 2.61 & 354.61 & $\mathrm{C}_{21} \mathrm{H}_{40} \mathrm{O}_{4}$ & $\mathrm{a}, \mathrm{b}, \mathrm{c}$ \\
\hline 24 & Isohumulone & 1367 & 4.95 & - & - & 356.29 & $\mathrm{C}_{21} \mathrm{H}_{30} \mathrm{O}_{5}$ & $a, b, c$ \\
\hline 25 & n.i. & 1430 & 0.60 & 0.74 & 0.30 & - & - & $a, b, c$ \\
\hline 26 & Stigmasterol & 1478 & 1.57 & - & 7.38 & 412.70 & $\mathrm{C}_{29} \mathrm{H}_{48} \mathrm{O}$ & $a, b, c$ \\
\hline 27 & $\beta$-sitosterol & 1479 & 0.64 & - & 5.59 & 414.38 & $\mathrm{C}_{29} \mathrm{H}_{50} \mathrm{O}$ & $a, b, c$ \\
\hline 28 & $\gamma$-sitosterol & 1506 & 2.61 & - & 2.14 & 414.38 & $\mathrm{C}_{29} \mathrm{H}_{50} \mathrm{O}$ & $a, b, c$ \\
\hline 29 & $\beta$-tocopherol & 1559 & 0.56 & - & - & 416.36 & $\mathrm{C}_{28} \mathrm{H}_{48} \mathrm{O}_{2}$ & $a, b, c$ \\
\hline 30 & $\gamma$-tocopherol & 1618 & 0.73 & - & - & 416.36 & $\mathrm{C}_{28} \mathrm{H}_{48} \mathrm{O}_{2}$ & $a, b, c$ \\
\hline 32 & Lupeol & 1671 & - & - & 6.84 & 426.38 & $\mathrm{C}_{30} \mathrm{H}_{50} \mathrm{O}$ & $\mathrm{a}, \mathrm{b}, \mathrm{c}$ \\
\hline 33 & $\alpha$-amyrin & 1716 & - & - & 1.97 & 426.38 & $\mathrm{C}_{30} \mathrm{H}_{50} \mathrm{O}$ & $\mathrm{a}, \mathrm{b}, \mathrm{c}$ \\
\hline 35 & Vitamin E & 1761 & - & 20.86 & 18.04 & 430.38 & $\mathrm{C}_{29} \mathrm{H}_{50} \mathrm{O}_{2}$ & $a, b, c$ \\
\hline 36 & Ethyl iso-allocholate & 1780 & - & - & 10.60 & 436.63 & $\mathrm{C}_{26} \mathrm{H}_{44} \mathrm{O}_{5}$ & $a, b, c$ \\
\hline 37 & Betulin & 1782 & 1.11 & - & 1.10 & 442.38 & $\mathrm{C}_{30} \mathrm{H}_{50} \mathrm{O}_{2}$ & $a, b, c$ \\
\hline 38 & Inotodiol & 1792 & - & 2.63 & - & 442.38 & $\mathrm{C}_{30} \mathrm{H}_{50} \mathrm{O}_{2}$ & $a, b, c$ \\
\hline 40 & Lupeol acetate & 1847 & - & - & 2.60 & 468.39 & $\mathrm{C}_{32} \mathrm{H}_{52} \mathrm{O}_{2}$ & $\mathrm{a}, \mathrm{b}, \mathrm{c}$ \\
\hline 41 & Cycloartenol acetate & 1914 & - & 0.99 & 4.88 & 468.76 & $\mathrm{C}_{32} \mathrm{H}_{52} \mathrm{O}_{2}$ & $\mathrm{a}, \mathrm{b}, \mathrm{c}$ \\
\hline 42 & 13,14-epoxyoleanan-3-ol, acetate & 1916 & - & 1.18 & - & 470.37 & $\mathrm{C}_{31} \mathrm{H}_{50} \mathrm{O}_{3}$ & $\mathrm{a}, \mathrm{b}, \mathrm{c}$ \\
\hline 44 & Barringtogenol C & 2174 & - & 3.53 & - & 490.36 & $\mathrm{C}_{30} \mathrm{H}_{50} \mathrm{O}_{5}$ & $\mathrm{a}, \mathrm{b}, \mathrm{c}$ \\
\hline 45 & 3-O-Acetyl-6-methoxy-cycloartenol & 2194 & - & 1.68 & 0.77 & 498.40 & $\mathrm{C}_{33} \mathrm{H}_{54} \mathrm{O}_{3}$ & $\mathrm{a}, \mathrm{b}, \mathrm{c}$ \\
\hline & Total identified & & 99.30 & 99.24 & 99.63 & & & \\
\hline & Fatty acids & & 7.04 & 5.57 & 1.04 & & & \\
\hline & Sulfur compounds & & 0.86 & 20.24 & 8.55 & & & \\
\hline & Monoterpene hydrocarbons & & - & 0.91 & - & & & \\
\hline & Oxygenated sesquiterpene & & - & 0.93 & - & & & \\
\hline & Oxygenated diterpene & & 30.92 & 10.24 & 6.50 & & & \\
\hline & Triterpenes & & 1.11 & 6.16 & 12.52 & & & \\
\hline & Fatty acid esters & & 48.31 & 29.93 & 19.02 & & & \\
\hline & Vitamin precursor & & 1.29 & - & - & & & \\
\hline & Phytoesterol & & 4.82 & 0.99 & 19.99 & & & \\
\hline & Vitamins & & - & 20.86 & 18.04 & & & \\
\hline & Alpha acids & & 4.95 & - & - & & & \\
\hline & Steroidal compound & & - & - & 10.60 & & & \\
\hline & Others & & - & 3.41 & 3.37 & & & \\
\hline
\end{tabular}

${ }^{a}$ Compounds listed in order of elution in column HP-5MS; ${ }^{\mathbf{b}} \mathbf{R I}=$ Identification based on retention index (RI) using a homologous series of $n$-alkane $\mathrm{C}_{7}-\mathrm{C}_{40}$ on Agilent HP-5MS column; ${ }^{\mathbf{c}} \mathbf{M S}=$ identification based on comparison of mass spectra using Wiley 275 libraries; Relative area $(\%)=$ percentage of the area occupied by the compounds in the chromatogram; $m / z=$ mass values; n.i. $=$ not identified; $(-)=$ absent. 
The projection of the main classes of compounds by principal component analysis indicates that factor 1 represents $68 \%$ of the variability of the classes found in the extracts of the leaves, flowers, and fruits of G. integrifolia (Fig. 1). In factor 2, the extracts of leaves and flowers showed a positive correlation, this can be explained because both presented as majority class fatty acid esters (48.2 and 29.9 $\%$, respectively) (Table 1, Fig. 1). However, the extracts of leaves and fruits presented negative correlation in factor 2 , the fruit extract showed high concentrations of phytosterols (18.0\%) and vitamins $(20.0 \%)$, while in the leaves extract was identified lower concentrations of phytosterols $(4.8 \%)$ and did not identified vitamins (Table 1, Fig. 1). In general, the class projection indicates variation between the chemical composition of extracts, mainly those related to the esters of fatty acids, oxygenated diterpenes, vitamins, phytosterols, and sulfur compounds (Fig. 1).

A class of predominant compounds was the esters of fatty acids in flowers $(29.9 \%)$, fruits, $(19.0 \%)$ and leaves $(48.3 \%)$. The vitamins were observed in the flowers $(20.9 \%)$ and fruits $(18.0 \%)$. The sulfur compounds of the characteristic alliaceous odor of this plant were predominant in the flowers $(20.2 \%)$, followed by fruits $(8.6 \%)$ and a smaller concentration in the leaves $(0.9 \%)$ (Table 1, Fig. 1). The major compounds in the crude extract in the flowers were ethyl ester of linoleic acid (14\%) (Fig. 2) and disulfide, bis (2-sulfhydryl ethyl) (11.9 \%) (Fig. 3); in the fruits, they were ethyl isoallocholate (10.6\%) and stigmasterol (7.4\%); and in the leaves, they were phytol (30.9\%) (Fig. 4), linoleic acid methyl ester (30.5\%) and methyl palmitate $(10.9 \%)$. Some major compounds were found only in one part of the plant such as linoleic acid $(6.0 \%)$ and isohumulone $(5.0 \%)$ just in the leaves; disulfide, bis(2-sulfhydryl ethyl) (11.9\%) and methyl linoleate (5.2 $\%)$ were found only in the flowers; and lupeol $(6.8 \%)$ and ethyl iso-allocholate $(10.6 \%)$ were present just in the fruits (Table 1).

The main biomolecules of organosulfate class present in the extract from $G$. integrifolia flower were disulfide, bis(2-sulfhydryl ethyl) $\left(\mathrm{C}_{4} \mathrm{H}_{10} \mathrm{~S}_{4}\right)$ (Fig. 2, Table 1), methyl (methylsulfinyl) methyl sulfide $\left(\mathrm{C}_{3} \mathrm{H}_{8} \mathrm{~S}_{3}\right), 1,2,4$-trithiolane $\left(\mathrm{C}_{2} \mathrm{H}_{4} \mathrm{~S}_{3}\right)$, and 2,4-dithiapentane $\left(\mathrm{C}_{3} \mathrm{H}_{8} \mathrm{~S}_{2}\right)$ (Table 1) with compounds with four, three, and two sulfur atoms, respectively.

Besides the chemical composition, the biological potential of three $G$. integrifolia extracts was evaluated against $A$. aegypti thirdstage larvae and pupae. Overall, all the tested

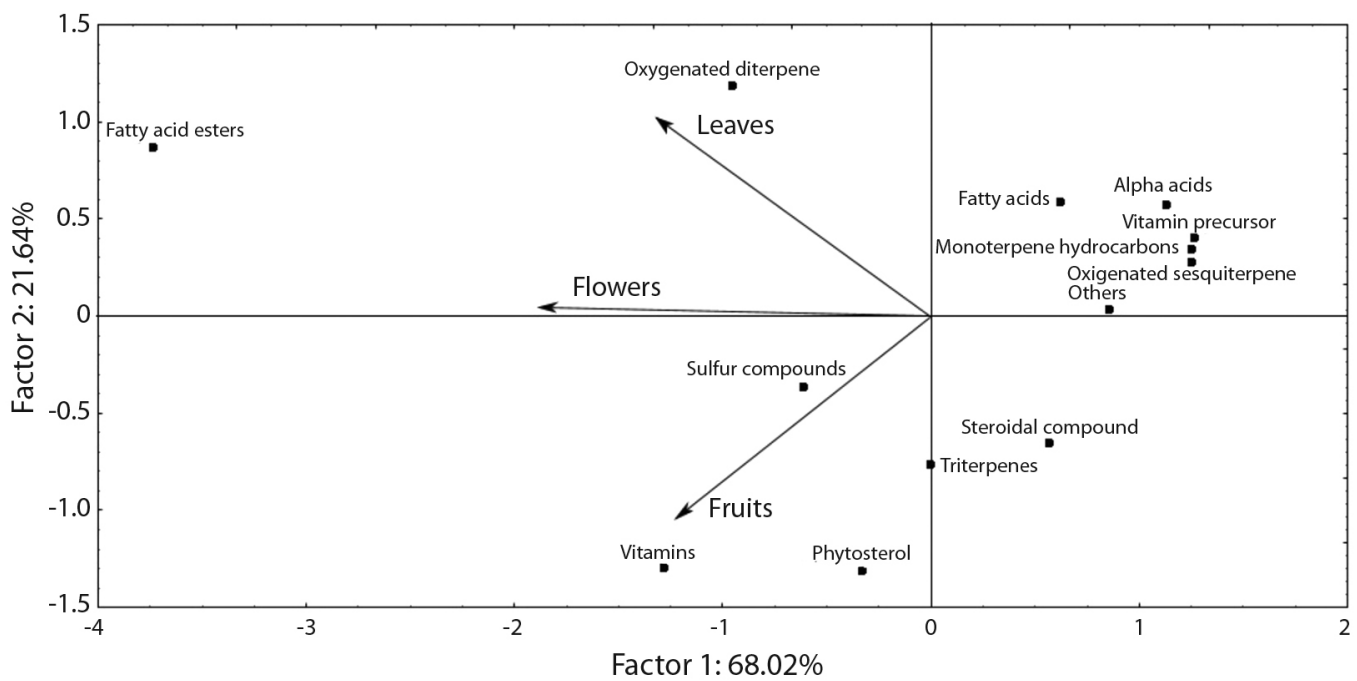

Fig. 1. Biplot of principal component analysis scores and loadings for the gas chromatography and mass spectrometry representing the projection of chemical classes of the crude extract from leaves, flowers, and fruits of Gallesia integrifolia. 


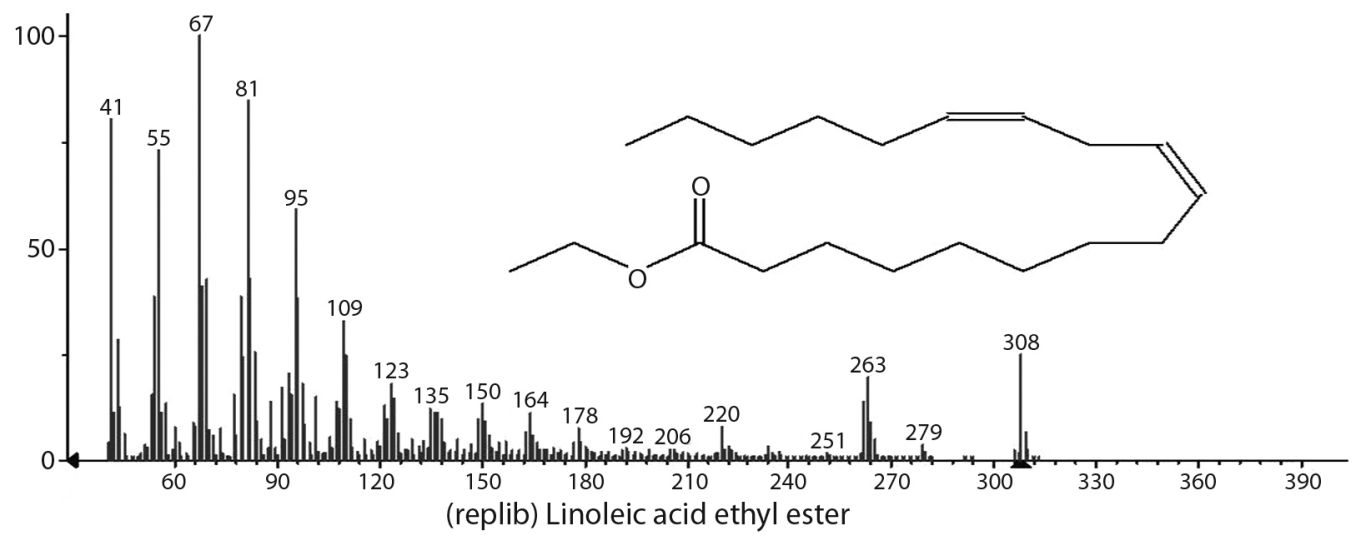

Fig. 2. Mass spectrum of linoleic acid ethyl ester of the extract from Gallesia integrifolia flower (14.0\%) and fruit (2.3\%) obtained by gas chromatography-mass spectrometry.

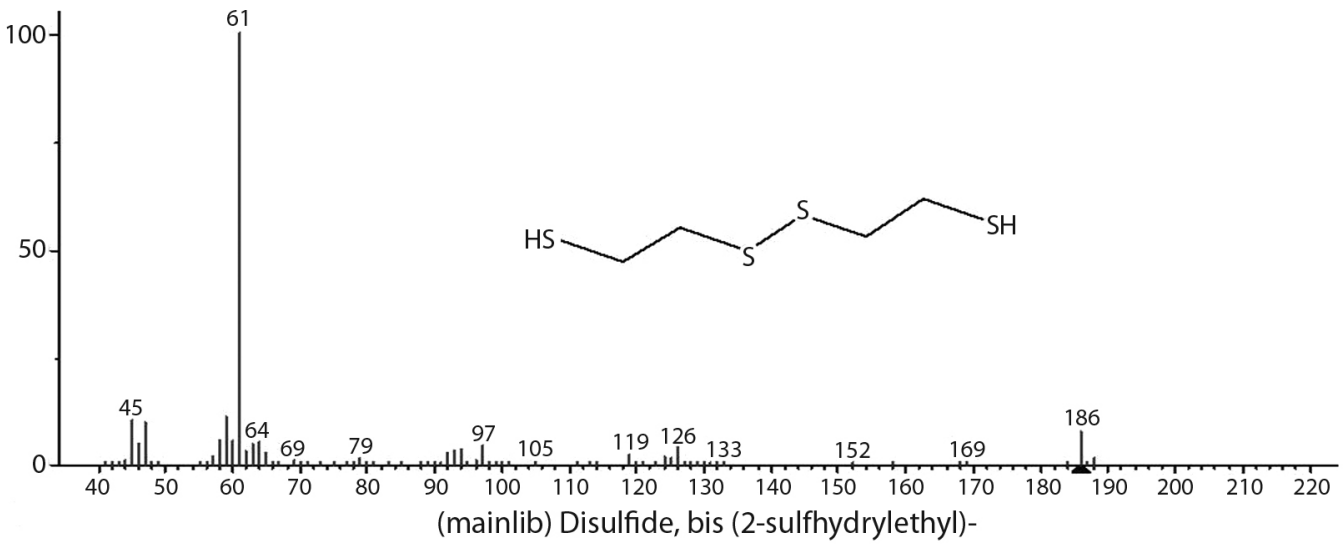

Fig. 3. Mass spectrum of disulfide, bis(2-sulfhydryl ethyl) of the extract from Gallesia integrifolia flower (11.9\%) obtained by gas chromatography-mass spectrometry.

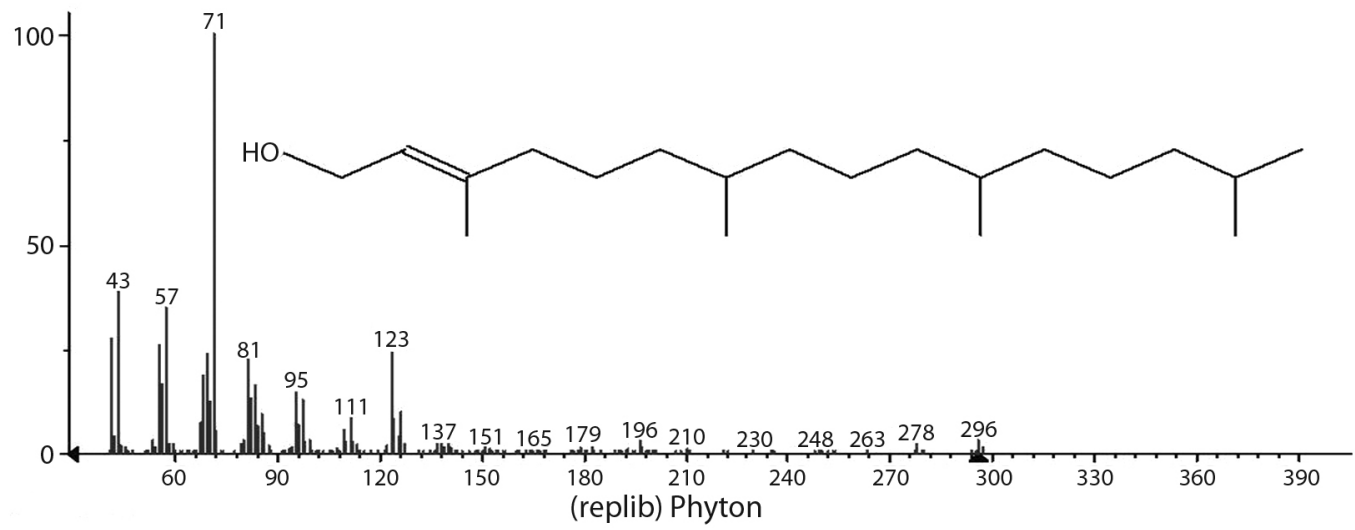

Fig. 4. Mass spectrum of phytol of extract from Gallesia integrifolia leaves (30.9\%) obtained by gas chromatography-mass spectrometry. 
samples were more efficient for the larvae as well as for the pupae than the positive control. The best lethal concentrations were for the larvae when compared to pupae, as seen in the extract of $G$. integrifolia flowers where the $\mathrm{LC}_{99.9}$ for larvae was $0.032 \mathrm{mg} / \mathrm{mL}$, and for pupae was $\mathrm{LC}_{99.9}$ of $0.969 \mathrm{mg} / \mathrm{mL}$, which is $3 \%$ more effective than in larvae when compared to pupae. Followed by the raw fruit extract the $\mathrm{LC}_{99.9}$ for larvae was $0.124 \mathrm{mg} /$ $\mathrm{mL}$, and for pupae was $\mathrm{LC}_{99.9}$ of $6.086 \mathrm{mg} /$ $\mathrm{mL}$. However, the extract from $G$. integrifolia leaves was $5 \%$ more effective for larvae when compared to pupae (Table 2).

To help elucidate the action mechanism of these crude extracts, acetylcholinesterase enzyme (AChE) was evaluated using the crude extracts from $G$. integrifolia flowers, fruits, and leaves and temephos (commercial organophosphate) as a positive control (Table 3 ).

For the inhibiting activity test of acetylcholinesterase enzyme, the crude flower extract presented inhibitory effect at the concentration of $0.00019 \mathrm{mg} / \mathrm{mL}$, followed by the positive

TABLE 2

Lethal concentration $\left(\mathrm{LC}_{50}\right.$ and $\mathrm{LC}_{99.9}$ ) and confidence interval (CI) of Gallesia integrifolia extracts from flowers, fruits, and leaves against Aedes aegypti larvae and pupae by probit analysis

\begin{tabular}{lcccc}
\multirow{2}{*}{ G. integrifolia extract of } & \multicolumn{2}{c}{ Larvae } & \multicolumn{2}{c}{ Pupae } \\
& $\mathrm{LC}_{50}(\mathrm{mg} / \mathrm{mL})[\mathrm{CI}]$ & $\mathrm{LC}_{99.9}(\mathrm{mg} / \mathrm{mL})[\mathrm{CI}]$ & $\mathrm{LC}_{50}(\mathrm{mg} / \mathrm{mL})[\mathrm{CI}]$ & $\mathrm{LC}_{99.9}(\mathrm{mg} / \mathrm{mL})[\mathrm{CI}]$ \\
Leaves & $0.094 \pm 0.001^{\mathrm{b}}$ & $0.278 \pm 0.001^{\mathrm{c}}$ & $2.177 \pm 0.177^{\mathrm{a}}$ & $14.040 \pm 0.581^{\mathrm{a}}$ \\
& {$[0.091-0.093]$} & {$[0.279-0.282]$} & {$[2.000-2.354]$} & {$[13.459-14.622]$} \\
Flowers & $0.006 \pm 0.001^{\mathrm{a}}$ & $0.032 \pm 0.001^{\mathrm{a}}$ & $0.036 \pm 0.004^{\mathrm{a}}$ & $0.969 \pm 0.026^{\mathrm{a}}$ \\
& {$[0.006-0.006]$} & {$[0.030-0.032]$} & {$[0.035-0.037]$} & {$[0.968-0.970]$} \\
Fruits & $0.025 \pm 0.002^{\mathrm{a}}$ & $0.124 \pm 0.003^{\mathrm{b}}$ & $1.037 \pm 0.080^{\mathrm{a}}$ & $6.086 \pm 0.039^{\mathrm{a}}$ \\
& {$[0.023-0.027]$} & {$[0.120-0.126]$} & {$[0.840-1.152]$} & {$[5.704-6.307]$} \\
Temephos (control) & $0.398 \pm 0.050^{\mathrm{c}}$ & $1.140 \pm 0.060^{\mathrm{d}}$ & $234.370 \pm 22.090^{\mathrm{b}}$ & $443.640 \pm 14.870^{\mathrm{b}}$ \\
& {$[0.348-0.448]$} & {$[1.080-1.200]$} & {$[212.280-256.460]$} & {$[428.770-458.510]$} \\
\hline
\end{tabular}

$\mathrm{LC}_{50}=$ lethal concentration that kills $50 \%$ of $A$. aegypti larvae and pupae populations; $\mathrm{LC}_{99.9}=$ lethal concentration that kills $99.9 \%$ of $A$. aegypti larvae and pupae populations; $\mathrm{CI}=$ confidence interval; Positive control = commercial organophosphate temephos; Equal letters in the same column indicate that there is no significant difference among treatments by Duncan's test $(\mathrm{P} \leq 0.05)$.

TABLE 3

Inhibiting activity of acetylcholinesterase enzyme at different concentrations of extracts from Gallesia integrifolia flowers, fruits, and leaves by bioautographic method

$\begin{array}{ccccccccccc}\begin{array}{c}\text { Concentration } \\ (\mathrm{mg} / \mathrm{mL})\end{array} & \text { Leaf } & \text { Flower } & \text { Fruit } & \text { PC } & \text { Concentration }(\mathrm{mg} / \mathrm{mL}) & \text { Leaf } & \text { Flower } & \text { Fruit } & \text { PC } \\ 50 & +++ & +++ & +++ & +++ & 0.0488 & - & + & + & ++ \\ 25 & ++ & +++ & +++ & +++ & 0.0244 & - & + & + & + \\ 12.5 & + & ++ & ++ & +++ & 0.0122 & - & + & - & + \\ 6.25 & + & ++ & ++ & +++ & 0.0061 & - & + & - & + \\ 3.125 & + & + & ++ & +++ & 0.0030 & - & + & - & + \\ 1.5625 & + & + & ++ & +++ & 0.0015 & - & + & - & + \\ 0.7812 & + & + & + & ++ & 0.00076 & - & + & - & + \\ 0.3906 & + & + & + & ++ & 0.00038 & - & + & - & + \\ 0.1953 & - & + & + & ++ & 0.00019 & - & + & - & - \\ 0.0976 & - & + & + & ++ & 0.00009 & - & - & - & -\end{array}$

Concentration $=\mathrm{mg} / \mathrm{mL} ; \mathrm{PC}=$ positive control $($ commercial organophosphate temephos $) ;(+++)=$ strong inhibition of acetylcholinesterase enzyme; $(++)=$ moderate inhibition; $(+)=$ weak inhibition; $(-)=$ absence of inhibition. 
control at $0.00038 \mathrm{mg} / \mathrm{mL}$, by the fruit extract $(0.0244 \mathrm{mg} / \mathrm{mL})$ and the leaf extract $(0.3906$ $\mathrm{mg} / \mathrm{mL})$. When compared to the ex situ test $\left(\mathrm{LC}_{99.9}\right)$ with $A$. aegypti larvae, the extracts from flowers, fruits, and leaves were 16.8, 0.5, and $0.07 \%$, respectively, less effective than in the bioautographic test in TLC.

\section{DISCUSSION}

The chemical identification of crude extracts of $G$. integrifolia flowers, fruits, and leaves was carried out by CG-MS and it was verified the presence of esters of fatty acids as the predominant class in the three extracts: leaf extract (48.3\%), flower extract (29.9 $\%)$, and fruit extract (19\%). The amount and distribution of fatty acids varied in the several species of the plants, besides being affected by seasonal influences (Kozlowski \& Pallardy, 1996). The fatty acids found in the leaves are responsible for controlling water loss to the environment during gas exchanges, and protect the plant against the nutrient loss due to the high incidence of ultraviolet rays and intense rainfall (Kozlowski \& Pallardy, 1996); in the flowers, as well as in the leaves, the fatty acids are part of the surface impermeabilization, avoiding water loss, and part of the pollination process as they are in the chemical composition of flower nectar (Levin, McCue, \& Davidowitz, 2017) whereas, in the fruits and seeds, these acids act as a barrier to moist diffusion, as a form of protection, because it is a reserve organ to the embryo (Esau, 1986; Kunst \& Samuels, 2009). In general, fatty acids act on the cellular structure of vegetables, growth, nutrition, senescence, and protection against phytopathogens and the environment (Meï et al., 2015; Li, Xu, Li-Beisson, \& Philippar, 2016; Silva et al., 2016).

The linoleic acid ethyl ester found in the extract from flowers and fruits (Fig. 2) is a long-chain polar compound with antibacterial and anti-inflammatory activities utilized in the cosmetic industry (Jelenko, Wheeler, Anderson, Callaway, \& McKinley, 1975; Park et al., 2014). The linoleic acid ethyl ester as well as the linolenic acid methyl ester are present in the dark green leaves because they are part of the apolar lipid fraction of plants (Simopoulos, 2002). There are no reports on the activity of these molecules against $A$. aegypti, but fatty acid methyl ester had $\mathrm{LC}_{99.9}$ of $0.17 \mathrm{mg} / \mathrm{mL}$ in Culex quinquefasciatus larvae (Silva et al., 2016), indicating insecticide effect against larvae of this insect.

Ethyl iso-allocholate found in the fruits $(10.6 \%)$ does not present cytotoxicity in zebrafish and can induce apoptosis through caspases signaling pathway, causing morphological alterations in the cell membranes (Thakur \& Ahirwar, 2019). According to Cooper, Thi, Chamberlain, Pio, \& Lowenberger (2007), this signaling is also possibly responsible for $A$. aegypti mortality because it acts as a biochemical cascade, triggering a proteolytic effect. Another compound with biological potential found in $G$. integrifolia is methyl palmitate (leaves 10.9, flowers 4.7, and fruits $5.0 \%$ ), an antagonist for muscarinic receptors with broad toxicity against phytophagous mites such as Tetranychus cinnabarinus (Boisduval) at 10 $\mathrm{mg} / \mathrm{mL}$ (Wang et al., 2009).

Moreover, phytol found at high concentration in the extract from $G$. integrifolia leaves (Fig. 4) chemically corresponds to a branched long-chain aliphatic alcohol that gives hydrophobic characteristic to chlorophyll molecules; however, when it is broken by chlorophyllase, phytol is converted into phytanic acid with an important biological effect on thermogenic activities and inhibitor of teratogenic effects of retinol (Marquez, 2003). Phytol also has anti-inflammatory activity by releasing histamine (26.9 \%), serotine, and bradykinin (49.9\%), and prostaglandin (68\%) compared to control (diclofenac $5 \mathrm{mg} / \mathrm{kg}$ ) (Phatangare, Deshmukh, Murade, Hase, \& Gaje, 2017). Phytol has been reported as an inhibitor of proteins and enzymes from bacteria (Ghaneian, Ehrampoush, Jebali, Hekmatimoghaddam, \& Mahmoudi, 2015). The compound stigmasterol (Table 1) obtained from $G$. integrifolia fruit extract has been related to the inhibition of acetylcholinesterase enzyme in human embryonic 


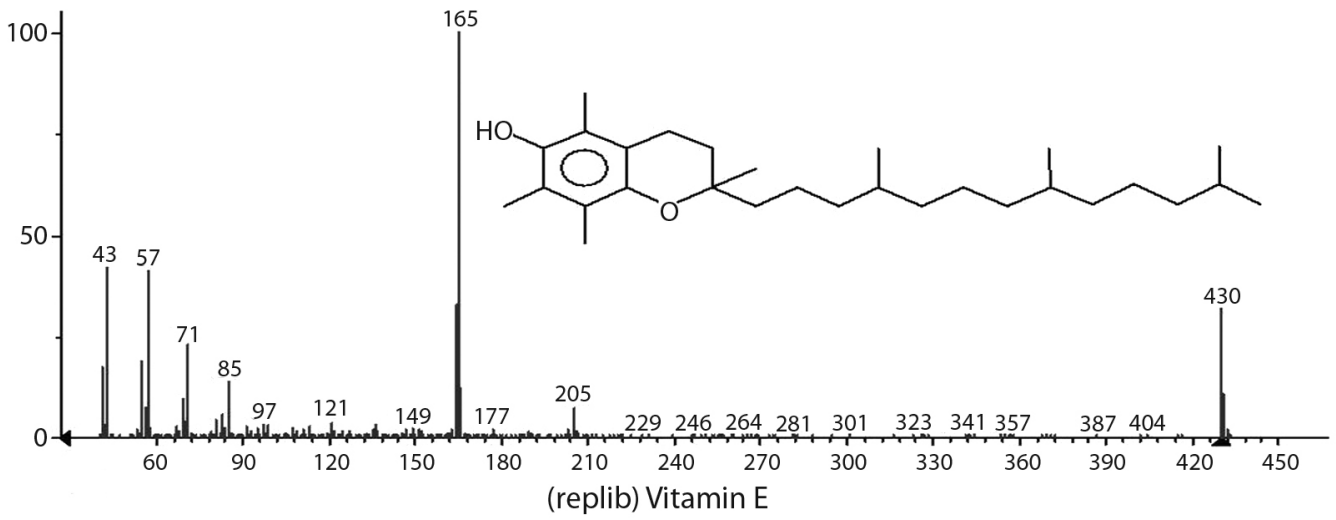

Fig. 5. Mass spectrum of vitamin E identified in the extract from Gallesia integrifolia flower (20.9 \%) and fruit (18.0\%) obtained by gas chromatography-mass spectrometry.

kidney cells (HEK293), that is the same mechanism of action of organophosphate insecticides (Alout et al., 2012; Gade et al., 2017).

Vitamin E (Fig. 5) was identified at a high concentration in the extracts of $G$. integrifolia flower $(20.9 \%)$ and fruit (18.0\%). Vitamin E, which consists of tocopherols and tocotrienols, is found in plants giving them photoprotective and antioxidant characteristics (Havaux, Eymery, Porfirova, Rey, \& Dormann, 2005). Vitamin E was not detected in the extract from $G$. integrifolia leaves but the presence of its precursors, $\beta$-tocopherol and $\gamma$-tocopherol, was identified.

Sulfur compounds were predominant in $G$. integrifolia flower extract (20.2\%), followed by fruits $(8.6 \%)$ and in a small concentration in the leaf extract $(0.9 \%)$ (Table 1$)$. The major chemical compounds were disulfide, bis(2sulfhydryl ethyl) (flowers $11.9 \%$ ) (Fig. 3). This biomolecule presents antioxidant potential due to its high potential to eliminate free radicals (Murugesan, Pandiyan, Saravanakumar, Moodley, \& Mackraj, 2019). Other present compounds were 2,3,5-trithiahexane (flowers 6.2 and fruits $4.7 \%$ ), 1,2,4-trithiolane (flowers 1.1 , fruits 1.8 , and leaves $0.9 \%$ ) and 2,4-dithiapentane (flowers 1.1 and fruits $2.1 \%$ ). All these biomolecules can be related to the characteristic alliaceous odor of the plant, mainly during flowering to attract specific pollinators (Kishimoto, Maeda, Haketa, \& Okubo, 2014).
When the insecticidal activity against $A$. aegypti was analyzed, the values of $\mathrm{LC}_{99.9}$ for the control of $A$. aegypti was $0.032 \mathrm{mg} / \mathrm{mL}$ for larvae and $0.969 \mathrm{mg} / \mathrm{mL}$ for pupae, using the extract from G. integrifolia flower (Table 2), whereas in the positive control (temephos) at $\mathrm{LC}_{99.9}$ was $1.140 \mathrm{mg} / \mathrm{mL}$ for larvae and 443.64 $\mathrm{mg} / \mathrm{mL}$ for pupae. However, the extract from $G$. integrifolia flowers was $3.6 \%$ more effective against $A$. aegypti larvae than the positive control. This indicates that this crude extract may be an alternative to be used in the control of this insect. Nevertheless, these values are much over the values of $0.0000031 \mathrm{mg} /$ $\mathrm{mL}$ for temephos against Rockefeller strain larvae cited by Jonny et al. (2015). According to Cheng, Chang, Chang, Tsai, \& Chen (2003), compounds that presented $\mathrm{LC}_{50}<0.100 \mathrm{mg} /$ $\mathrm{mL}$ are considered active as larvicides on $A$. aegypti, and highly active with $\mathrm{LC}_{50}<0.05$ $\mathrm{mg} / \mathrm{mL}$. The crude extract of $G$. integrifolia leaves showed active $\left(\mathrm{LC}_{50}=0.094 \mathrm{mg} / \mathrm{mL}\right)$ on A. aegypti larvae and the crude extracts of flowers $\left(\mathrm{LC}_{50}=0.006 \mathrm{mg} / \mathrm{mL}\right)$ and fruits $\left(\mathrm{LC}_{50}\right.$ $=0.025 \mathrm{mg} / \mathrm{mL})$ of $G$. integrifolia demonstrating highly effective in controlling the larvae of A. aegypti (Kiran, Bhavani, Devi, Rao, \& Reddy, 2006).

The lethal concentrations found for larvae were lower than the ones for pupae, as it occurred in the extract from $G$. integrifolia fruit in which the $\mathrm{LC}_{99.9}$ for larvae was 
$0.124 \mathrm{mg} / \mathrm{mL}$, and $\mathrm{LC}_{99.9}$ of $6.086 \mathrm{mg} / \mathrm{mL}$ for pupae, which was $4.9 \%$ more effective for A. aegypti larvae than pupae. Moreover, the extract from $G$. integrifolia leaves was $5 \%$ more effective for larvae when compared to pupae (Table 2). The intoxication pathways of the product are distinct for larvae and pupae because in the pupal stage, there is no food intake and, therefore, there is no compound intake. However, in this stage, the compounds can act on the cutaneous surface of the pupae and cause death by protein denaturation, enzymatic inhibition, and/or disintegration of the cell membrane (Consoli \& Oliveira, 1994; Regnault, 1997; Carvalho et al., 2003; Cavalca, Lolis, Reis, \& Nonato, 2010). In the larval stage, the culicid is more susceptible, because, besides the contact by the external membranes, when ingesting food, it can intake compounds found in the water, increasing its potential of action (Procópio et al., 2015).

Extracts of $G$. integrifolia presented insecticide activity for the holometabolic phase of A. aegypti when compared to the positive control (commercial organophosphate temephos). When analyzing $\mathrm{LC}_{99.9}$ of $A$. aegypti larvae, it was verified that the best results were for the extract from G. integrifolia flower, followed by the extract from fruits, and then from leaves, that was 35.6-, 9.2-, and 4.1-fold more effective, respectively, than the positive control (Table 2). The greatest insecticide activity ( $\mathrm{P} \leq$ $0.05)$ was for the extract from $G$. integrifolia flower with $\mathrm{LC}_{99.9}$ of $0.032 \mathrm{mg} / \mathrm{mL}$ for larvae and $0.969 \mathrm{mg} / \mathrm{mL}$ for pupae, which is 3.9-fold more effective than the extract from $G$. integrifolia fruit and 8.7-fold more effective than the extract from $G$. integrifolia leaves for larvae.

$\mathrm{LC}_{99.9}$ of the crude ethanolic extract from $G$. integrifolia flowers is 3.2-fold more effective to control $A$. aegypti larvae than Lippia alba essential oil, 3.7-fold more effective than Ocimum gratissimum essential oil, 4.3-fold more than Cymbopogon citratus essential oil, and 9-fold more effective than Eucalyptus citriodora (current name Corymbia citriodora) essential oil (Cavalcanti, Morais, Lima, \& Santana, 2004; Vera et al., 2014). This indicates the larvicide potential of the extract from $G$. integrifolia flowers as a phytoinsecticide. In addition, the extract from $G$. integrifolia flowers has $20.2 \%$ of sulfur compounds that can be related to this greater insecticide activity efficiency and the sulfur compounds were also verified in the extract from $G$. integrifolia fruits $(8.5 \%)$ and leaves $(0.9 \%)$ (Table 1$)$.

The major biomolecules of the organosulfurates class found in the extract from $G$. integrifolia flower were disulfide, bis(2-sulfhydryl ethyl) $\left(\mathrm{C}_{4} \mathrm{H}_{10} \mathrm{~S}_{4}\right)$ (Fig. 3), methyl (methylsulfinyl) methyl sulfide $\left(\mathrm{C}_{3} \mathrm{H}_{8} \mathrm{~S}_{3}\right)$, 1,2,4-trithiolane $\left(\mathrm{C}_{2} \mathrm{H}_{4} \mathrm{~S}_{3}\right)$, and 2,4-dithiapentane $\left(\mathrm{C}_{3} \mathrm{H}_{8} \mathrm{~S}_{2}\right)$ (Table 1) with compounds containing four, three, or two sulfur atoms. Garlic essential oil (Allium tuberosum and Allium sativum) has been utilized to control insect larvae and/ or as a repellent of mosquitoes such as Aedes spp., Anopheles spp., and Culex spp. due to the presence of sulfur atoms in their composition (Denloye et al., 2003; Trongtokit et al., 2005). Liu, Liu, Zhou, \& Liu (2014) observed that Allium macrostemon essential oil with $98.1 \%$ of sulfur compounds presented $\mathrm{LC}_{99.9}$ of 0.139 $\mathrm{mg} / \mathrm{mL}$ and the methyl propyl disulfide isolates had $\mathrm{LC}_{99.9}$ of $0.151 \mathrm{mg} / \mathrm{mL}$, whereas dimethyl trisulfide presented $\mathrm{LC}_{99.9}$ of $0.058 \mathrm{mg} / \mathrm{mL}$ against Aedes albopictus. The concentrations of the extract from $G$. integrifolia flowers were 1.5 -fold more efficient than A. tuberosum essential oil and 2-fold more efficient than allyl methyl trisulfide $\left(\mathrm{C}_{4} \mathrm{H}_{8} \mathrm{~S}_{3}\right)$ (Liu, Liu, Chen, Zhou, \& Liu, 2015).

Another plant with sulfur compounds in the essential oil is Petiveria alliacea that has $35.3 \%$ of dibenzyl disulfide $\\left(\mathrm{C}_{14} \mathrm{H}_{14} \mathrm{~S}_{2}\right)$ (Zoghbi, Andrade, \& Maia, 2002; Kerdudo et al., 2015) and insecticide activity against $A$. aegypti larvae with $\mathrm{LC}_{99.9}$ of $0.023 \mathrm{mg} / \mathrm{mL}$ (Hartmann, Silva, Walter, \& Jeremias, 2018), similarly to what was found in the extract from G. integrifolia flowers $\left(\mathrm{LC}_{99.9}\right.$ of $0.036 \mathrm{mg} /$ $\mathrm{mL}$ ). Pseudocalymma alliaceum (current name Mansoa alliacea) presents, in the composition of leaf essential oil, sulfur molecules such as $11.8 \%$ diallyl sulphide $\left(\mathrm{C}_{6} \mathrm{H}_{10} \mathrm{~S}\right), 50 \%$ diallyl disulphide $\left(\mathrm{C}_{6} \mathrm{H}_{10} \mathrm{~S}_{2}\right)$, and $10.4 \%$ trisulfide, 
di-2-propenyl $\left(\mathrm{C}_{6} \mathrm{H}_{10} \mathrm{~S}_{3}\right)$, and insecticide activity with $\mathrm{LC}_{50}$ of $0.267 \mathrm{mg} / \mathrm{mL}$ and $\mathrm{LC}_{99.9}$ of $0.547 \mathrm{mg} / \mathrm{mL}$ against $C$. quinquefasciatus pupae (Echegoyen et al., 2014). This suggests that the insecticide activity may be related to the sulfur molecules in the chemical composition of the essential oil from these plants.

The biological activity of sulfur compounds against $A$. aegypti is still not well understood. However, sulfur compounds can form disulfide bridges (covalent bonds) with amino acids and proteins that are important to keep the protein structure and the catalytic functions of enzymes; however, exogenous sulfur compounds can cause the destabilization of protein quaternary structure and enzymatic inactivation (Belitz, Grosch, \& Schieberle, 2009; Berkmen, 2012). The greater the number of sulfur atoms in a molecule, then the greater the number of polysulfide bridges (-Sn-) are present in the chemical structures of the compound. Consequently, the water solubility will be smaller, increasing the chemical affinity of the molecule with the structure of the cell wall and membranes, mainly consisting of ergosterol and chitin which in microbial cells promote the membrane rupture and cell imbalance (Cahagnier, 1988; Peacock \& Goosey, 1989; Levinson, 2016). This suggests that these results can be related to the cell wall permeability, physical, and chemical characteristics of solubility, and molecular absorption in lipophilic and hydrophilic media, inherent to the test in A. aegypti larvae and pupae (Benson, 2005; Brain, Green, \& Apia, 2007). In addition, Kumar (2015) reported that sulfur compounds in A. sativum such as allicin $\left(\mathrm{C}_{6} \mathrm{H}_{10} \mathrm{~S}_{2} \mathrm{O}\right)$ act by inhibiting acetylcholinesterase enzyme up to the concentration of $0.05 \mathrm{mg} / \mathrm{mL}$ because they present a greater chemical affinity by anion sites of cholinesterase (Mahfouz, Metcalf, \& Fukuto, 1969). These data corroborate our studies because the presence of sulfur atoms in the flower $(20.2 \%)$ and fruit $(8.6 \%)$ extract of $G$. integrifolia can be related to the best results of the acetylcholinesterase enzyme inhibition in relation to the leaf extract (0.9 $\%)$. This indicates that the extracts from $G$. integrifolia strongly inhibit the acetylcholinesterase enzyme, mainly when correlated to the presence of sulfur compounds. However, more studies are necessary to identify the active compounds with this biological activity.

The yield of crude extract from $G$. integrifolia flowers, fruits, and leaves was 8.2, 9.1 , and $17.3 \%$, respectively. The major compounds of the ethanolic crude extract from $G$. integrifolia leaves are phytol (30.9\%), linolenic acid methyl ester (30.5\%), and methyl palmitate $(10.9 \%)$, from flowers are vitamin E (20.9 \%), linolenic acid methyl ester (14\%), disulfide, bis(2-sulfhydryl ethyl) (11.9\%), and phytol $(10.2 \%)$, and from fruits are vitamin E $(18 \%)$ and ethyl iso-allocholate $(10.6 \%)$. Only extracts from fruits and flowers present a high concentration of vitamin $\mathrm{E}$ whereas only flower extract presents a high concentration of disulfide, bis(2-sulfhydryl ethyl). There are organosulfurates compounds such as 1,2,4-trithiolane in flowers (1.1), fruits (1.8), and leaves $(0.9 \%), 2,3,5$-trithiahexane in flowers $(6.2 \%)$ and fruits $(4.7 \%), 2,4$-dithiapentane in flowers $(1.1 \%)$ and fruits $(2.1 \%)$, and disulfide, bis (2-sulfidril ethyl) in flowers $(11.9 \%)$. The flower extract has greater larvicidal activity on A. aegypti $\mathrm{LC}_{99.9}$ of $0.032 \mathrm{mg} / \mathrm{mL}$ and the smallest concentration for acetylcholinesterase enzyme, which is of $0.00019 \mathrm{mg} / \mathrm{mL}$. The flower extract is 35.6-fold more efficient for A. aegypti larvae than the positive control, and $12.8 \%$ more efficient for the anticholinesterase activity test. The crude extracts from $G$. integrifolia fruits, leaves and, mainly flowers are a potential alternative bioinsecticides to control A. aegypti larvae and pupae.

Ethical statement: authors declare that they all agree with this publication and made significant contributions; that there is no conflict of interest of any kind; and that we followed all pertinent ethical and legal procedures and requirements. All financial sources are fully and clearly stated in the acknowledgements section. A signed document has been filed in the journal archives. 


\section{ACKNOWLEDGMENTS}

The authors thank Universidade Paranaense, Fundação Araucária, Coordenação de Aperfeiçoamento de Pessoal de Nível Superior - Brazil (CAPES) -finance code 001-, Conselho Nacional de Desenvolvimento Científico e Tecnológico (CNPq) for the fellowship and financial support.

\section{RESUMEN}

Extracto crudo del árbol tropical Gallesia integrifolia (Phytolaccaceae) para el control de larvas de Aedes aegypti (Diptera: Culicidae). Introducción: los fitoinsecticidas son alternativas para el control de insectos en diferentes etapas, Gallesia integrifolia (Spreng.) Harms, familia Phytolacaceae, conocida popularmente como pau d'alho, árbol de ajo y guararema en Brasil, es conocida por su fuerte olor aliáceo debido a la presencia de moléculas de azufre en la planta. Esta especie presenta actividad biológica y potencial efecto insecticida que aún no está explotado. Objetivo: El objetivo de este estudio fue evaluar la actividad biológica del extracto crudo etanólico de las hojas, flores y frutos de G. integrifolia en el control de las larvas y pupas de la tercera etapa de Aedes aegypti. Métodos: El material botánico fue recolectado en la ciudad de Umuarama, Paraná, Brasil (2346'16" S \& 5319'38" W), a una altitud de $442 \mathrm{~m}$ y los frutos de G. integrifolia fueron recolectados en mayo de 2017 y las hojas y flores en diciembre del mismo año. Los extractos crudos de hojas, flores y frutos de G. integrifolia se prepararon por técnica de maceración dinámica. La composición química de los extractos se determinó por cromatografía de gases acoplada a espectrometría de masas. La actividad insecticida de los extractos crudos de $G$. integrifolia fue evaluada en larvas y pupas de $A$. aegypti en concentraciones entre 0.001 a 25 $000 \mathrm{mg} / \mathrm{mL}$, y las concentraciones letales que matan $50 \%$ $\left(\mathrm{CL}_{50}\right)$ y $99.9 \%\left(\mathrm{CL}_{99.9}\right)$ de larvas fueron determinados por análisis de probit. La actividad anticolinesterasa fue evaluada por método bioautográfico en concentraciones de 0.000095 a $50 \mathrm{mg} / \mathrm{mL}$. Resultados: El rendimiento de los extractos crudos de G. integrifolia fue de 8.2, 9.1 y $17.3 \%$ para flores, frutos y hojas, respectivamente. La composición química de los extractos de $G$. integrifolia se caracterizó por la presencia de ésteres de ácidos grasos, fitosteroles, vitaminas, diterpenos oxigenados y compuestos organosulfurados. El extracto de las flores presentó alta cantidad de compuestos de azufre (20.2\%) como disulfuro, bis(2-sulfhidril etilo) (11.9\%), 2,3,5-tritiahexano (6.2\%), 1,2,4-tritiolano (1.1\%) y 2,4-ditiapentano (1.1 $\%$ ). En relación con la actividad insecticida, el extracto de las flores mostró una gran actividad con $\mathrm{CL}_{99.9}$ de 0.032 $\mathrm{mg} / \mathrm{mL}$ y $\mathrm{CL}_{99.9}$ de $0.969 \mathrm{mg} / \mathrm{mL}$ en larvas y pupas de $A$. aegypti, respectivamente, y la inhibición más alta de la enzima acetilcolinesterasa $(0.00019 \mathrm{mg} / \mathrm{mL})$ ex situ. El extracto de las flores presentó actividad anticolinesterasa y larvicida, 12.8 y $35.6 \%$, respectivamente, mayor que el control temephos. Conclusiones: Este estudio abre nuevas perspectivas sobre el uso de extractos de G. integrifolia como alternativa bioinsecticida para el control de larvas y pupas de A. aegypti.

Palabras clave: anticolinesterasa; disulfuro; bis(2-sulfhidril etilo); pau d'alho; semioquímico; compuestos de azufre.

\section{REFERENCES}

Adams, R.P. (2017). Identification of Essential Oil Components by Gas Chromatography/Mass Spectrometry. Gruver, USA: Texensis Publishing.

Akisue, M.K., Akisue, G., \& Oliveira, F. (1986). Pharmacognostic characterization of pau d'alho Gallesia integrifolia (Spreng.) Harms. Revista Brasileira de Farmacognosia, 1, 166-182.

Alout, H., Labbe, P., Berthomieu, A., Djogbenou, L., Leonetti, J.P., Fort, P., \& Weill, M. (2012). Novel AChE inhibitors for sustainable insecticide resistance management. PLoS One, 7(10), 1-8.

Arunachalam, K., Ascêncio, S.D., Soares, I.M., Aguiar, R.W.S., Silva, L.I., Oliveira, R.G., ... Martins, D.T.O. (2016). Gallesia integrifolia (Spreng.) Harms: in vitro and in vivo antibacterial activities and mode of action. Journal of Ethnopharmacology, 184, 128-137.

Bakar, M.A., Aqueel, M.A., Raza, A.B.M., Ullah, M.I., Sohail, M., \& Ochoa, J.M. (2017). Evaluation of few essential oils for the management of parasitic bee mites, Varroa destructor (Acari: Varroidae) in Apis mellifera L. colonies. Pakistan Journal of Agricultural Research, 49(6), 2005-2010.

Barbosa, L.C.A., Teixeira, R.R., \& Demuner, A.J. (1997). Vitamin E and other chemical constituents of the leaves of Gallesia gorazema. Fitoterapia, 68, 514-519.

Belitz, H.D., Grosch, W., \& Schieberle, P. (2009). Food Chemistry. Berlin, Germany: Springer-Verlag Berlin Heidelberg.

Bellinato, D.F., Medeiros, P.F.V., Araújo, S.C., Martins, A.J., Lima, J.B.P., \& Valle, D. (2016). Resistance status to the insecticides temephos, deltamethrin, and diflubenzuron in Brazilian Aedes aegypti populations. Biomed Research International, 2016, 1-13.

Benelli, G., \& Mehlhorn, H. (2016). Declining malaria, rising of dengue and Zika virus: insights for mosquito vector control. Parasitology Research, 115, $1747-1754$ 
Benelli, G., Maggi, F., Pavela, R., Murugan, K., Govindarajan, M., Vaseeharan, B., ... Higuchi, A. (2017). Mosquito control with green nanopesticides: towards the one health approach? A review of non-target effects. Environmental Science and Pollution Research International, 25(11), 10184-10206.

Benitez-Trinidad, A.B., Herrera-Moreno, J.F., VázquezEstrada, G., Verdín-Betancourt, F.A., Sordo, M., Ostrosky-Wegman, P., ... Rojas-García, A.E. (2015). Cytostatic and genotoxic effect of temephos in human lymphocytes and HepG2 cells. Toxicology in Vitro, 29, 779-786.

Benson, H.A.E. (2005). Transdermal drug delivery: penetration enhancement techniques. Current Drug Delivery, 2, 23-33.

Berkmen, M. (2012). Production of disulfide-bonded proteins in Escherichia coli. Protein Expression and Purification, 82, 240-251.

Bonato, C.M., Cavalca, P.A.M., \& Lolis, M.R.B. (2010). Homeopathic and larvicide effect of Eucalyptus cinerea essential oil against Aedes aegypti. Brazilian Archives of Biology and Technology, 53, 835-843.

Braga, I.A., \& Valle, D. (2007). Aedes aegypti: insecticides, mechanisms of action and resistance. Epidemiologia e Serviços de Saúde, 16, 279-293.

Brain, K.R., Green, D.M., \& Apia, M. (2007). In-vitro human skin penetration of the fragrance material geranyl nitrile. Toxicology in Vitro, 21, 133-138.

Ministério da Saúde. (2020). Monitoramento dos casos de arboviroses urbanas transmitidas pelo Aedes aegypti (dengue, chikungunya e Zika), Semanas Epidemiológicas 01 a 52. Boletim Epidemiológico, 51(02), 1-16. Retrieved from https://portalarquivos2.saude.gov.br/ images/pdf/2020/janeiro/20/Boletim-epidemiologico-SVS-02-1-.pdf

Ministério da Saúde. (2010). Farmacopeia Brasileira (5 th $^{\text {th }}$ Ed.). Brasília, Brasil: Anvisa.

Cahagnier, B. (1988). Qualita microbiologique des grains et teneursen ergosterol. Industries Alimentaires Agricoles, 1, 5-15.

Camargo, M.F., Santos, A.H., Oliveira, A.W.S., Abräo, N., Alves, R.B.N., \& Isac, E. (1998). Evaluation of the residual action of the larvicide temephos over Aedes aegypti (díptera-culicidae) in different types of containers. Revista de Patologia Tropical, 27, 65-70.

Carvalho, A.F.U., Melo, V.M.M., Craveiro, A.A., Machado, M.I.L., Bantim, M.B., \& Rabelo, E.F. (2003). Larvicidal activity of the essential oil from Lippia sidoides Cham. against Aedes aegypti Linn. Memórias do Instituto Oswaldo Cruz, 98, 569-571.

Cavalca, P.A.M., Lolis, M.I.G.A., Reis, B., \& Nonato, C.M. (2010). Homeopathic and larvicide effect of
Eucalyptus cinerea essential oil against Aedes aegypti. Brazilian Archives of Biology and Technology, 53(4), 835-843.

Cavalcanti, E.S.B., Morais, S.M.D., Lima, M.A.A., \& Santana, E.W.P. (2004). Larvicidal activity of essential oils from Brazilian plants against Aedes aegypti L. Memórias do Instituto Oswaldo Cruz, 99(5), 541-544.

Cheng, S.S., Chang, H.T., Chang, S.T., Tsai, K.H., \& Chen, W.J. (2003). Bioactivity of selected plant essential oils against the yellow fever mosquito Aedes aegypti larvae. Bioresource Technology, 89, 99-102.

Čolović, M., \& Krstić, D. (2013). Acetylcholinesterase inhibitors: pharmacology and toxicology. Current Neuropharmacology, 11(3), 315-335.

Consoli, R.A.G.B., \& Oliveira, R.L. (1994). Principais Mosquitos de Importância Sanitária no Brasil. Rio de Janeiro, Brazil: Editora Fiocruz.

Cooper, D.M., Thi, E.P., Chamberlain, C.M., Pio, F., \& Lowenberger, C. (2007). Aedes Dronc: a novel ecdysone-inducible caspase in the yellow fever mosquito, Aedes aegypti. Insect Molecular Biology, 16(5), 563-572.

Corrêa-Filho, J. (1984). Dicionário das Plantas Úteis do Brasil e das Exóticas Cultivadas. Brasília, Brazil: Ministério da Agricultura, IBDF.

Costa, J.G.M., Rodrigues, F.F.G., Angélico, E.C., Silva, M.R., Mota, M.L., Santos, N.K.A., ... Lemos, T.L.G. (2005). Chemical-biological study of the essential oils of Hyptis martiusii, Lippia sidoides and Syzygium aromaticum against larvae of Aedes aegypti and Culex quinquefasciatus. Revista Brasileira de Farmacognosia, 15, 304-309.

Denloye, A.A., Makanjuola, W.A., \& Babalola, O.O. (2003). Toxicity and repellent effects of crude aqueous extracts of garlic (Allium sativum) on larval and adult Anopheles mosquitoes. African Entomology, 11, 287-290.

Dias, A.S., Tanure, A.M., \& Bertonceli, R.M. (2018). In vitro effect of extract of garlic's wood (Gallesia integrifolia Sprengel) Harms on engorged ticks and larvae of Ripicephalus Boophilus microplus. Scientific Electronic Archives, 11, 99-103.

Echegoyen, G.C., Pacheco, P.R., Hernández, S.M., Vega, E.J., Rivera, L.L., Hernandez, A.N., \& Armas, G.R. (2014). Inhibition of the growth and development of mosquito larvae of Culex quinquefasciatus (Diptera: Culicidae) treated with extract from leaves of Pseudocalymma alliaceum (Bignoniaceae). Asian Pacific Journal of Tropical Medicine, 7(8), 594-601.

Esau, K. (1986). Anatomia das Plantas com Sementes. São Paulo, Brazil: Edgard Blucher. 
Fernandes, F.F., Souza Freitas, E.P., da Costa, A.C., \& da Silva, I.G. (2005). Larvicidal potential of Sapindus saponaria to control of the cattle tick Boophilus microplus. Pesquisa Agropecuaria Brasileira, 40, 1243-1245.

Fofana, D., Beugré, J.M.V., Yao-Acapovi, G.L., \& Lendzele, S.S. (2019). Risk of dengue transmission in cocody (Abidjan, Ivory Coast). Journal of Parasitology Research, 4914137, 1-7.

Freixa, B., Vila, R., Vargas, L., Lozano, N., Adzet, T., \& Cañigueral, S. (1998). Screening for antifungal activity of nineteen Latin American plants. Phytotherapy Research, 12, 427-430.

Gade, S., Rajamanikyam, M., Vadlapudi, V., Nukala, K.M., Aluvala, R., Giddigari, C., ... Upadhyayula, S.M. (2017). Acetylcholinesterase inhibitory activity of stigmasterol \& hexacosanol is responsible for larvicidal and repellent properties of Chromolaena odorata. Biochimica et biophysica acta General subjects, 1861(3), 541-550.

Ghaneian, M.T., Ehrampoush, M.H., Jebali, A., Hekmatimoghaddam, S., \& Mahmoudi, M. (2015). Antimicrobial activity, toxicity and stability of phytol as a novel surface disinfectant. Environmental Health Engineering and Management, 2, 13-16.

González, M.A., Sosa, M.A.R., Bautista, Y.E.V., Fernández, L.D., Prada, M.B., Guerrero, K.A., \& Elbal, P.M.A. (2019). Micro-environmental features associated to container-dwelling mosquitões (Diptera: Culicidae) in an urban cemetery of the Dominican Republic. Revista de Biologia Tropical, 67(1), 132-145.

Hartmann, I., Silva, A., Walter, M.E., \& Jeremias, W.J. (2018). Investigation of the larvicidal effect of guiné (Petiveria alliacea) on larvae of mosquitoes of the species A. aegypti. Revista Virtual de Química, 10(3), $1-13$.

Hassler, M. (2018). World plants: synonymic checklists of the vascular plants of the world (version Nov 2018). In Y. Roskov, G. Ower, T. Orrell, D. Nicolson, N. Bailly, P.M. Kirk, \& L. Penev (Eds.), Species 2000 \& ITIS Catalogue of Life, 2019 Annual Checklist. Leiden, the Netherlands. Retrieved from www.catalogueoflife.org/col/

Havaux, M., Eymery, F., Porfirova, S., Rey, P., \& Dormann, P. (2005). Vitamin E protects against photoinhibition and photooxidative stress in Arabidopsis thaliana. The Plant Cell, 17(12), 3451-3469.

Jelenko, C., Wheeler, M.L., Anderson, A.P., Callaway, B.D., \& McKinley, J.C. (1975). Studies in burns: XIV, healing in burn wounds treated with ethyl linoleate alone or in combination with selected topical antibacterial agents. Annals of Surgery, 182, 562-566.

Jonny, E.D., Silva, A.M., Fantinatti, E.C.S., \& Silva, M.N. (2015). Resistance of Aedes aegypti (Diptera:
Culicidae) to temephos in Paraná State, Brazil. Revista Colombiana de Entomologia, 41(2), 205-211.

Kerdudo, A., Gonnot, V., Njoh Ellong, E., Boyer, L., Michel, T., Adenet, S., ... \& Fernandez, X. (2015). Essential oil composition and biological activities of Petiveria alliacea L. from Martinique. Journal of Essential Oil Research, 27(3), 186-196.

Kiran, S.R., Bhavani, K., Devi, P.S., Rao, B.R.R., \& Reddy, K.J. (2006). Composition and larvicidal activity of leaves and stem essential oils of Chroxylon swietenia DC against Aedes aegypti and Anopheles stephensi. Bioresource Technology, 97, 2481-2484.

Kishimoto, K., Maeda, H., Haketa, T., \& Okubo, N.O. (2014). Odor components and the control of odor development in ornamental cabbage. Journal Japanese Society for Horticultural Science, 83(3), 252-258.

Kozlowski, T.T., \& Pallardy, S.G. (1996). Physiology of Woody Plants. California, USA: Academic Press, Elsevier.

Kumar, S. (2015). Dual inhibition of acetylcholinesterase and butyrylcholinesterase enzymes by allicin. Indian Journal of Pharmacology, 47(4), 444-446.

Kunst, L., \& Samuels, L. (2009). Plant cuticles shine: advances in wax biosynthesis and export. Current Opinion in Plant Biology, 12, 721-727.

Laurentino, A.O.M., Medeiros, F.D., Oliveira, J., Rosa, N., Gomes, T.M., Peretti, E.M., ... Fortunato, J.J. (2019). Effects of prenatal exposure to temephos on behavior and social interaction. Neuropsychiatric Disease and Treatment, 15, 669-673.

Levin, E., McCue, M.D., \& Davidowitz, G. (2017). More than just sugar: allocation of nectar animo acids and fatty acids in a Lepidopteran. Proceedings Biological Sciences, 284, 1-7.

Levinson, W. (2016). Microbiologia Médica e Imunologia. Porto Alegre, Brazil: AMGH Editora Ltda.

Li, N., Xu, C., Li-Beisson, Y., \& Philippar, K. (2016). Fatty Acid and lipid transport in plant cells. Trends in Plant Science, 21(2), 145-158.

Liu, X.C., Liu, Q., Chen, X.B., Zhou, L., \& Liu, Z.L. (2015). Larvicidal activity of the essential oil from Tetradium glabrifolium fruits and its constituents against Aedes albopictus. Pest Management Science, $71(11), 1582-1586$.

Liu, X.C., Liu, Q., Zhou, L., \& Liu, Z.L. (2014). Evaluation of larvicidal activity of the essential oil of Allium macrostemon Bunge and its selected major constituent compounds against Aedes albopictus (Diptera: Culicidae). Parasites \& Vectors, 7, 1-5.

Macoris, M.L.G., Camargo, M.F., Silva, I.G., Takaku, L., \& Andrighetti, M.T. (1995). Modificações da 
susceptibilidade de Aedes (Stegomyia) aegypti ao temephos. Journal of Tropical Pathology, 24, 31-40.

Mahfouz, A.M.M., Metcalf, R.L., \& Fukuto, T.R. (1969). Influence of the sulfur atom on the anticholinesterase and insecticidal properties of thioether N-methylcarbamates. Journal of Agricultural and Food Chemistry, 17, 917-922.

Marquez, L.U.M. (2003). The role of chlorophyll in human feeding: a review. Revista Brasileira de Ciencias Farmaceuticas, 30(3), 227-242.

Marston, A., Kissling, J., \& Hostettmann, K.A. (2002). A rapid TLC bioautography method for the detection of acetylcholinesterase and butyrylcholinesterase inhibitors in plants. Phytochemistry, 13, 51-54.

Meï, C., Michaud, M., Cussac, M., Albrieux, C., Gros, V., Maréchal, E., ... Rébeillé, F. (2015). Levels of polyunsaturated fatty acids correlate with growth rate in plant cell cultures. Scientific Reports, 5, 15207.

Morais, S.S., Bautista, A.R., \& Viana, B.F. (2000). Acute toxicity studies of insecticides $\left(\mathrm{DL}_{50} \mathrm{e} \mathrm{CL}_{50}\right)$ to Scaptotrigona tubiba (Smith) (Hymenoptera: Apidae): by contact route. Anais da Sociedade Entomológica do Brasil, 29, 31-37.

Mrdaković, M., Ilijin, L., Vlahović, M., Matić, D., Gavrilović, A., Mrkonja, A., \& Perić-Mataruga, V. (2016). Acetylcholinesterase (AChE) and heat shock proteins (Hsp70) of gypsy moth (Lymantria dispar L.) larvae in response to long-term fluoranthene exposure. Chemosphere, 159, 565-569.

Murugesan, S., Pandiyan, A., Saravanakumar, L., Moodley, K., \& Mackraj, I. (2019). Protective role of wild garlic on isoproterenol-induced myocardial necrosis in wistar rats. Journal of Ethnopharmacology, 237, 108-115.

Park, S.Y., Seetharaman, R., Ko, M.J., Kim, D.Y., Kim, T.H., Yoon, M.K., ... Choi, Y.W. (2014). Ethyl linoleate from garlic attenuates lipopolysaccharide-induced pro-inflammatory cytokine production by inducing heme oxygenase-1 in RAW264.7 cells. International Immunopharmacology, 19(2), 253-261.

Pavela, R. (2015). Essential oils for the development of eco-friendly mosquito larvicides: A review. Industrial Crops and Products, 76, 174-187.

Peacock, G.A., \& Goosey, M.W. (1989). Separation of fungal sterols by normal-phase high-performance liquid chromatography: application to the evaluation of ergosterol biosynthesis inhibitors. Journal of Chromatography A, 469, 293-304.

Pérez, D. (2002). Etnobotánica medicinal y biocidas para malaria en la región Ucayali. Folia Amazónica, 13, 87-108.
Phatangare, N.D., Deshmukh, K.K., Murade, V.D., Hase, G.J., \& Gaje, T.R. (2017). Isolation and characterization of phytol from Justicia gendarussa Burm. f.-An anti-inflammatory compound. Journal of Pharmacognosy and Phytochemistry, 9(6), 864-872.

Procópio, T.F., Fernandes, K.M., Pontual, E.V., Ximenes, R.M., de Oliveira, A.R.C., Souza, C.S., ... Napoleão, T.H. (2015). Schinus terebinthifolius leaf extract causes midgut damage, interfering with survival and development of Aedes aegypti larvae. PLoS One, 10(5), e0126612.

Raimundo, K.F., Bortolucci, W.C., Silva, E.S., Pereira, A.F.B., Sakai, O.A., Piau Junior, R., ... Gazim, Z.C. (2017). Chemical composition of garlic wood (Gallesia integrifolia) (Phytolaccaceae) volatile compounds and their activity on cattle tick. Australian Journal of Crop Science, 11, 1058-1067.

Raimundo, K.F., Bortolucci, W.C., Glamočlija, J., Soković, M., Gonçalves, J.E., Linde, G.A., ... Gazim, Z.C. (2018). Antifungal activity of Gallesia integrifolia fruit essential oil. Brazilian Journal of Microbiology, 49, 229-235.

Regnault, R.C. (1997). The potential of botanical essential oils for insect pest control. Integrated Pest Management Reviews, 2, 25-34.

Sambuichi, R.H.R., Mielke, M.S., \& Pereira, C.E. (2009). Nossas árvores conservação, uso e manejo de árvores nativas no sul da Bahia. Bahia, Brazil: Fapesb Editus.

Silva, A.J., Buzzi, F.C., Romanos, M.T.V., Wagner, T.M., Guimarães, A.F.P.C., Cechinel, V., \& Batista, R. (2013). Chemical composition and antinociceptive, anti-inflammatory and antiviral activities of Gallesia gorazema (Phytolaccaceae), a potential candidate for novel anti-herpetic phytomedicines. Journal of Ethnopharmacology, 150, 595-600.

Silva, L.N.D., Ribeiro-Neto, J.A., Valadares, J.M.M., Costa, M.M., Lima, L.A.R.S., Grillo, L.A.M., ... Barbosa, L.A. (2016). The influence of fatty acid methyl esters (FAMEs) in the biochemistry and the $\mathrm{Na}^{+} /$ $\mathrm{K}^{+}$-ATPase activity of Culex quinquefasciatus larvae. The Journal of Membrane Biology, 249(4), 459-467.

Silva, M.J.R., Vedoato, B.T.F., Lima, G.P.P., Moura, M.F., Coser, G.M.A.G., Watanabe, C.Y., \& Tecchio, M.A. (2017). Phenolic compounds and antioxidant activity of red and white grapes on different rootstocks. African Journal of Biotechnology, 16, 664-671.

Simopoulos, A.P. (2002). Omega-3 fatty acids in wild plants, nuts and seeds. Asia Pacific Journal of Clinical Nutrition, 11(6), 163-173.

Thakur, R.S., \& Ahirwar, B. (2019). A steroidal derivative from Trigonella foenum graecum L. that induces apoptosis in vitro and in vivo. Journal of Food and Drug Analysis, 27, 231-239. 
Trongtokit, Y., Rongsriyam, Y., Komalamisra, N., \& Apiwathnasorn, C. (2005). Comparative repellency of 38 essential oils against mosquito bites. Phytotherapy Research, 19, 303-309.

Vera, S.S., Zambrano, D.F., Méndez-Sanchez, S.C., Rodríguez-Sanabria, F., Stashenko, E.E., \& Luna, J.E.D. (2014). Essential oils with insecticidal activity against larvae of Aedes aegypti (Diptera: Culicidae). Parasitology Research, 113(7), 2647-2654.

Wang, Y.N., Wang, H.X., Shen, Z.J., Zhao, L.L., Clarke, S.R., Sun, J.H., ... Shi, G.L. (2009). Methyl palmitate, an acaricidal compound occurring in green walnut husks. Journal of Economic Entomology, 102(1), 196-202.

Yang, Z., Zhang, X., Duan, D., Song, Z., Yang, M., \& Li, S. (2009). Modifiel TLC bioautographic method for screening acetylcholinesterase inhibitors from plant extracts. Journal of Separation Science, 32(18), 3257-3259.

Zoghbi, M.G.B., Andrade, E.H.A., \& Maia, J.G.S. (2002). Volatile constituents from Adenocalymma alliaceum Miers and Petiveria alliacea L., two medicinal herbs of the Amazon. Flavour and Fragrance Journal, 17, 133-135. 